San Jose State University

SJSU ScholarWorks

Faculty Publications

Aerospace Engineering

October 2001

\title{
Introducing Cooperative Learning through a Faculty Instructional Development Program
}

Nikos J. Mourtos

San Jose State University, Nikos.Mourtos@sjsu.edu

E. L. Allen

San Jose State University

Follow this and additional works at: https://scholarworks.sjsu.edu/aero_eng_pub

Part of the Aerospace Engineering Commons

\section{Recommended Citation}

Nikos J. Mourtos and E. L. Allen. "Introducing Cooperative Learning through a Faculty Instructional Development Program" ASEE Journal of Engineering Education (2001): 669-675.

This Article is brought to you for free and open access by the Aerospace Engineering at SJSU ScholarWorks. It has been accepted for inclusion in Faculty Publications by an authorized administrator of SJSU ScholarWorks. For more information, please contact scholarworks@sjsu.edu. 


\section{Introducing Cooperative Learning through a Faculty Instructional Development Program}

NiKOS J. MOURTOS

Mechanical and Aerospace Engineering

San Jose State University

EMILY L. ALLEN

Chemical and Materials Engineering

San Jose State University

\section{ABSTRACT}

Cooperative Learning was officially introduced in the College of Engineering at San Jose State University in 1995 with a two-day workshop. The Faculty Instructional Development Program in the college maintains interest in the subjsect and provides support for instructors who use Cooperative Learning, through workshops and informal discussions (Conversations on Teaching). This paper discusses the effectiveness of the program in introducing, promoting, and implementing Cooperative Learning among the faculty and students in the college of engineering. A variety of performance criteria have been used in this assessment, some faculty-centered and some student-centered. The results indicate that although a relatively small percentage of faculty have chosen to adopt Cooperative Learning as a teaching tool in their courses, the impact on student attitudes and learning is significant, making the effort worthwhile.

\section{THE FACULTY INSTRUCTIONAL DEVELOPMENT PROGRAM}

The Faculty Instructional Development Program (FIDP) was initiated in 1995, with a goal to create a learning community within the College of Engineering (COE), whose focus is to improve instruction to better meet the needs of our students. Specifically, the objectives of the program are to introduce, promote, and implement the use of:

1. Cooperative Learning (CL).

2. Various teaching techniques to address the diverse learning styles of our students.

3. Multi-media, including the worldwide web.

An additional strategic objective is to:

4. Help interested faculty become mentors/coaches for other faculty, in the areas of innovative pedagogy and the use of technology in instruction.

The last objective is an important one for the following reasons:

a. The areas described in objectives 1-3 are quite broad and diverse. Therefore, it would not be feasible or effective for a single person to provide the expertise, leadership and mentorship necessary to promote all of these areas. b. It promotes leadership among new faculty, as they choose to take responsibility for one of these areas, develop their expertise in it, and serve as mentors for others.

c. It promotes collaboration and teamwork, as faculty work with each other to overcome challenges.

This paper focuses only on the first objective to introduce, promote, and implement $C L$ in the $\mathrm{COE}$.

\section{COOPERATIVE LEARNING}

Johnson, Johnson and Smith ${ }^{1}$ define $\mathrm{CL}$ as instruction, which involves students working in teams to accomplish a common goal, under conditions that involve positive interdependence, face-toface promotive interaction, individual as well as group accountability, and group processing. These conditions distinguish effective $\mathrm{CL}$ from other forms of group work. A student team may have as a goal to understand material presented in class or in a textbook, solve a problem, perform an experiment, design a product/process, write a report, or even take an exam as a team. Team skills such as leadership, communication, conflict management and decision making, are essential for effective $\mathrm{CL}$ and must be taught just like any other academic skill.

The purpose of this paper is not to show that $\mathrm{CL}$ is an effective teaching tool in engineering education. After all, it is now well documented that CL, when implemented properly, increases faculty instructional productivity, ${ }^{2}$ promotes higher order thinking skills in students, ${ }^{3}$ and improves student retention, ${ }^{4,5}$ especially in the freshman year. This is the reason why a significant investment in time and effort has been made in the $\mathrm{COE}$, to introduce and promote $\mathrm{CL}$. The purpose of this paper is to discuss the effectiveness of the FIDP in introducing, promoting, and implementing $\mathrm{CL}$ in the $\mathrm{COE}$.

\section{ASSESSMENT CRITERIA}

The performance criteria that were used to assess the effectiveness of the program are the following:

1. The percent of faculty who have attended at least one workshop on CL, from the time it was introduced in the college in spring 1995, till the end of 1999.

2. The percent of faculty who currently use CL in their classes, on a regular basis.

3. The frequency with which these professors use $\mathrm{CL}$ in their classes and the percentage of class time dedicated to CL activities.

4. The effectiveness of $\mathrm{CL}$ in improving student attitudes and learning, from the faculty perspective.

5. The effectiveness of $\mathrm{CL}$ in improving student attitudes and learning from the students' perspective. 


\section{FACULTY PARTICIPATION IN WORKSHOPS ON COOPERATIVE LEARNING}

Cooperative Learning was officially introduced in the COE before the start of the spring semester, in 1995. Karl Smith, ${ }^{6}$ a renowned expert on CL, was invited to offer a 2-day workshop, which was very well attended ( 67 out of 78 , or $86 \%$ of all full-time engineering faculty attended). The following year, the authors kept the interest alive with two 2-hour workshops (Mourtos, March 1996 and Allen, September 1996). Karl Smith revisited our school in January 1997 for another 2-day workshop and in April 1998 for a short presentation on CL, as part of an NSF-sponsored "Shaping the Future" one-day conference. Since that time, 2-hour CL workshops have been offered on a regular basis by the first author, one at a beginners' level in August for new faculty, and one for more experienced users in the fall. Thus, most of the engineering faculty have attended at least one workshop on CL and some of them as many as four.

In addition to formal workshops, the FIDP offers opportunities for faculty to discuss a variety of teaching-related issues on a monthly basis, in what we call "Conversations on Teaching." These gatherings promote informal interaction among the participants and are essential in meeting the goal of the FIDP "to create a learning community within the $\mathrm{COE}$ for the purpose of improving instruction." Cooperative learning has always been a hot topic in many of these conversations, as participants share successes and challenges from their own teaching.

\section{FACULTY USE OF COOPERATIVE LEARNING}

A questionnaire was emailed to all full-time faculty in fall 1998 to inquire about their use of CL. The response rate was $27 \%$ ( 21 out of 78 faculty), which is considered very good in surveys of this nature. ${ }^{7}$ The questions of the survey and the responses are summarized in Table 1.

Of the 19 faculty who use CL:

- $10(53 \%)$ were assistant professors, $3(16 \%)$ were associate professors, and $6(31 \%)$ were full professors at the time the survey was sent.
- $5(26 \%)$ are female and $14(74 \%)$ are male.

It is worth mentioning at this point that the two reasons given as a response to the second question in Table 1 represent the views of many engineering faculty, who have never tried using CL and did not respond to the questionnaire.

Perhaps at this point, we should ponder the following philosophical question: Why, after so much publicity in the COE and ASEE conferences, so many workshops offered and so many articles and books written about CL and its benefits, only a relatively small percentage of faculty (24\%) have decided to adopt CL in their classes?

In the authors' opinion, one possible answer is faculty attitudes towards cooperation in general. The current generation of engineering faculty has grown in a very competitive environment. This is true not only in the U.S. but all over the world. Many of us had to survive fierce competitions for grades in high school or compete in brutal entrance examinations to be admitted to engineering schools. Once in, the competition did not stop. In fact, it intensified. With a few exceptions in senior design projects, cooperation among students was seldom encouraged. Thus, during our years in school, an attitude of "live and let die" or "every man/woman for himself/herself" was embedded deep within our nature and this attitude is not easy to change. A small proof that cooperation, despite its well-known benefits, is not very common among engineering faculty, is the following fact: out of 439 research grants awarded in the COE between 1991 and 1998, only $67(15 \%)$ involved the collaboration of two or more faculty. In most of the cases where collaboration did take place, it was between two people.

The point is CL involves teaching students how to collaborate for the solution of engineering problems. Faculty will not naturally adopt CL in their classes, if they do not feel comfortable with the concept of cooperation. Hopefully, this attitude is changing.

On a more positive note, the faculty who have bought into CL have indeed formed a small learning community within the COE. They participate in our "Conversations on Teaching" on a regular basis and collaborate in projects that enhance teaching and learning.

\begin{tabular}{|c|c|c|c|c|}
\hline Questions & \multicolumn{4}{|c|}{ Responses } \\
\hline $\begin{array}{l}\text { 1. Are you currently } \\
\text { using CL in your } \\
\text { classes on a regular } \\
\text { basis? }\end{array}$ & \multicolumn{2}{|c|}{$\begin{array}{c}\text { Yes }=19 \text { faculty } \\
(24 \%)\end{array}$} & \multicolumn{2}{|c|}{$\begin{array}{c}\text { No }=2 \text { faculty } \\
(3 \%)\end{array}$} \\
\hline $\begin{array}{l}\text { 2. If you have } \\
\text { decided against using } \\
\text { CL, please state your } \\
\text { reasons: }\end{array}$ & \multicolumn{4}{|c|}{$\begin{array}{l}\text { (a) I tried CL and it didn't work. It is ineffective as a teaching method } \\
\text { because it does not allow me enough time to cover the material I need to } \\
\text { cover in my classes. } \\
\text { (b) Many of my students, when asked to work on problems in small groups, } \\
\text { engage instead in conversation or other activities (ex. reading the newspaper } \\
\text { or doing homework for other classes) unrelated to the task assigned. }\end{array}$} \\
\hline $\begin{array}{l}\text { 3. How often do you } \\
\text { use CL in your } \\
\text { classes? }\end{array}$ & $\begin{array}{l}\text { At least twice a } \\
\text { week }=7\end{array}$ & $\begin{array}{l}\text { Once a week } \\
=7\end{array}$ & $\begin{array}{l}\text { Twice a month } \\
=3\end{array}$ & $\begin{array}{l}\text { Once a month } \\
=2\end{array}$ \\
\hline $\begin{array}{l}\text { 4. What } \% \text { of class } \\
\text { time do you dedicate } \\
\text { to CL activities? }\end{array}$ & $\begin{array}{l}\text { More than } 50 \% \\
=7\end{array}$ & $\begin{array}{l}\text { Between } 40 \% \\
\text { and } 50 \%=3\end{array}$ & $\begin{array}{l}\text { Between } 20 \% \text { and } \\
30 \%=6\end{array}$ & $\begin{array}{l}\text { Less than } 10 \% \\
=3\end{array}$ \\
\hline
\end{tabular}

Table 1. Summary of CL use by COE faculty. 


\section{EFFECTS ON STUDENT ATTITUDES AND LEARNING; FACULTY PERSPECTIVE}

Three tools were used to assess faculty perspective on the effects of $\mathrm{CL}$ on student attitudes and learning: (a) a short questionnaire sent to all CL users, (b) a comparison of the distribution of grades in three courses with and without CL, and (c) comments solicited from faculty on why they use CL.

\section{A. Faculty Survey}

Three questions were emailed to CL users in fall 1998. Their responses are summarized in Table 2. It is evident that most professors who use CL believe that it does increase their students' understanding of the subject matter, even though (in most cases) they do not have any hard evidence to support their belief.

\section{B. Comparison of Grade Distributions with and without $C L$}

The distribution of grades in three courses, with and without $\mathrm{CL}$, was compared. These grades were based on absolute standards and therefore reflect student learning from the faculty point of view. The higher the grade a student receives in a course, the more he/she has learned in the particular subject matter. Thus, the percentage of A's and B's in a given course is a good indication (according to the faculty who assigned the grades) of how many students learned the material well enough to perform at a certain level ( $85 \%$ and above for A's, 70\% and above for B's). The results from this comparison are summarized in Table 3.

Table 3 shows that in two out of the three courses for which data were available, the percentage of students who earned A's and B's rose significantly when CL was used (from 67\% to $76 \%$ in ME 111 and from $66 \%$ to $81 \%$ in $\mathrm{AE} \mathrm{164).} \mathrm{Although} \mathrm{there} \mathrm{are} \mathrm{many} \mathrm{factors} \mathrm{that}$ may affect student performance in a course, this may be an indication that CL, when used properly, helps more students get more out of each course and perform at a higher level. This result is certainly in agreement with current research on teaching and learning in higher education. For example, McKeachie ${ }^{8}$ states that three elements of teaching make a difference in students' improvement of thinking skills: (a) student discussion, (b) explicit emphasis on problem-solving methodology using a variety of examples, and (c) verbalization of methods and strategies to encourage development of metacognition. The possibility that all three of these elements are present in the classroom on a daily basis is certainly much higher when CL is used, as students discuss and solve problems in small groups.

The third course for which data were available (AE 162) shows that $\mathrm{CL}$ did not change the distribution of grades much $(70 \%$ before, $69 \%$ after). However, in the time period when the data were collected, this course underwent many and significant changes, all of which made it much more challenging for the students. First, it was transformed from a pure lecture course to a lecture/laboratory combination with both physical and computational experiments.

\begin{tabular}{|c|c|c|c|}
\hline $\begin{array}{l}\text { Semester } \\
\text { Course } \\
\text { Offered }\end{array}$ & $\begin{array}{l}\text { No. of } \\
\text { Students } \\
\text { in the } \\
\text { Course }\end{array}$ & $\begin{array}{l}\mathrm{CL} \\
\text { used? }\end{array}$ & $\begin{array}{l}\% \text { of } \\
\text { A's } \\
\text { and } \\
\text { B's }\end{array}$ \\
\hline \multicolumn{4}{|c|}{ ME 111: Fluid Mechanics } \\
\hline Fall '87 & 39 & NO & $72 \%$ \\
\hline Spring ' 88 & 22 & NO & $59 \%$ \\
\hline \multicolumn{3}{|c|}{$\begin{array}{l}\text { Weighted average based on the total } \\
\text { number of students taught w/o CL: }\end{array}$} & $67 \%$ \\
\hline Fall '96, sec. 1 & 42 & YES & $57 \%$ \\
\hline Fall '96, sec. 2 & 34 & YES & $61 \%$ \\
\hline Fall '98 & 49 & YES & $94 \%$ \\
\hline Spring '99 & 69 & YES & $80 \%$ \\
\hline Fall ‘99 & 48 & YES & $81 \%$ \\
\hline \multicolumn{3}{|c|}{$\begin{array}{l}\text { Weighted average based on the total } \\
\text { number of students taught with CL: }\end{array}$} & $76 \%$ \\
\hline \multicolumn{4}{|c|}{ AE 162: Aerodynamics } \\
\hline Fall ' 88 & 23 & NO & $69 \%$ \\
\hline Fall '89 & 26 & NO & $73 \%$ \\
\hline Spring ‘90 & 22 & NO & $59 \%$ \\
\hline Fall ‘90 & 22 & NO & $73 \%$ \\
\hline Spring '91 & 27 & NO & $70 \%$ \\
\hline Fall ‘91 & 29 & NO & $86 \%$ \\
\hline Spring '92 & 27 & NO & $82 \%$ \\
\hline Fall '92 & 59 & No & $59 \%$ \\
\hline \multicolumn{3}{|c|}{$\begin{array}{l}\text { Weighted average based on the total } \\
\text { number of students taught w/o CL: }\end{array}$} & $70 \%$ \\
\hline Fall ‘93 & 37 & YES & $73 \%$ \\
\hline Fall '94 & 27 & YES & $59 \%$ \\
\hline Spring ‘97 & 19 & YES & $74 \%$ \\
\hline \multicolumn{3}{|c|}{$\begin{array}{l}\text { Weighted average based on the total } \\
\text { number of students taught with CL: }\end{array}$} & $69 \%$ \\
\hline \multicolumn{4}{|c|}{ AE 164: Advanced Fluid Mechanics } \\
\hline Spring ‘ 89 & 21 & NO & $66 \%$ \\
\hline \multicolumn{3}{|c|}{$\begin{array}{l}\text { Weighted average based on the total } \\
\text { number of students taught w/o CL: }\end{array}$} & $66 \%$ \\
\hline Spring ‘94 & 32 & YES & $72 \%$ \\
\hline Spring ‘95 & 30 & YES & $90 \%$ \\
\hline \multicolumn{3}{|c|}{$\begin{array}{l}\text { Weighted average based on the total } \\
\text { number of students taught with CL: }\end{array}$} & $81 \%$ \\
\hline
\end{tabular}

Table 3. Comparison of grade distribution in three courses, with and without $C L$.

\begin{tabular}{|l|c|c|c|c|}
\hline \multicolumn{1}{|c|}{ Questions } & Yes & No & Maybe & DNR \\
\hline $\begin{array}{l}\text { 1. Do you think CL } \\
\text { increases the students' } \\
\text { understanding of your } \\
\text { subject matter? }\end{array}$ & 12 & 0 & 4 & 3 \\
\hline $\begin{array}{l}\text { 2. Do you have any } \\
\text { evidence to support your } \\
\text { answer in question 1? }\end{array}$ & 14 & 5 & 0 & 0 \\
\hline $\begin{array}{l}\text { 3. What kind of } \\
\text { evidence? }\end{array}$ & $\begin{array}{l}\text { Anecdotal evidence } \\
=10 \text { faculty }\end{array}$ & $\begin{array}{l}\text { Surveys } \\
\text { =2 faculty }\end{array}$ & $\begin{array}{l}\text { Year-to-year exams and } \\
\text { course grades = 2 faculty }\end{array}$ \\
\hline
\end{tabular}

Table 2. Summary of faculty perspective on the effects of CL on student learning. 
Second, a significant design component was added in the form of three mini-design projects. These two changes require extensive report writing on the part of the students. Third, portfolio assessment was introduced in the course, giving the students more responsibility for their learning as well as its documentation. ${ }^{9}$ The new course requirements could have easily lowered the grades of many students, had not CL been available to help students sustain the same performance levels. Obviously, the grades in more courses need to be examined to gain confidence in this area.

\section{Faculty Comments on CL}

In fall 1999 comments were solicited from CL users. Faculty were asked to share their reasons why they use CL in their classes. Representative excerpts from these comments are included below.

- One of the main reasons I use non-lecture techniques, such as $C L$, is because that is one way I have found works for students to actually put in the time and effort to become familiar and confident with the subject material being focused on. Prior to using these methods, I was becoming more and more familiar with the subject, but the majority of the students were not. Now, we all are. (Chemical Engineering professor)

- ...With the first $C L$ sessions offered in the COE five years ago, I began to adapt these proven methods and practices, and I believe this greatly increased my effectiveness in laboratory instruction. I also applied the CL methodology in the lecture component of two key courses, MatE 25 and MatE 115... Both courses are challenging and tend to 'sort' those students serious about the program. It is my goal in these courses, to provide a basis on wbich to build "esprit de corps" amongst the students. I believe use of CL in the classroom belps to meet this objective. Students, whom I bad one or two years earlier in MatE 25, still interact with fellow group members, even though the students are in different programs. They are interested in each other and look out for each other. The same is true of our majors. For example, MatEMS graduates who took the MS oral exam this year, studied in base-groups pretty much parallel to those formed a year or so earlier in MatE 115. We had nine students take the orals and all passed; a first in my 19-year experience. Fellow faculty remarked that this year's orals were the best they could recall in terms of student preparation and delivery. There are a lot of reasons for this, but in my opinion, one of the main factors was the successful use of $C L$ in the delivery of Mat $E$ 115. I also offer a selfish reason for employing CL methods in the classroom. My SOTE (Student Opinion of Teaching Effectiveness) scores increased significantly because I have used $C L$. (Materials Engineering professor)

- I strongly believe in CL when applied appropriately. I think it leads to well-rounded students and, in many cases, more motivated students. I think CL puts more of a burden on the students to take responsibility for their education... and that's a good thing! Instead of just sitting taking in some small portion of the lecture, they are now more active participants with some accountability. (Aerospace Engineering professor)

- The primary reason that I use CL is because it prepares students for engineering work. In my own undergraduate education, except for laboratory classes, almost everytbing was learned individually. I feel that I received a strong technical understanding of engineering. However, when I worked in industry I came to realize that technical knowledge was far from enough to complete an engineering project. Teamwork and interaction were bigher contributors to the success of a project than being technically correct. I use CL because I think it encourages student interaction, and this translates to students who are better prepared to succeed in engineering careers. Tecbnical understanding is certainly important, but it is easier for a working engineer to acquire technical skills through continuing education, than team skills and personal interaction. I also feel that CL keeps the students' attention much better than traditional lectures. This is especially true with the move toward 75 or 150minute class periods, because the ability of a student to stay focused on the board for that length of time is very limited in a traditional lecture. (Civil Engineering professor)

In summary, faculty who use CL, do so because they find that CL increases student motivation and puts more responsibility for learning on the students. As a direct result, they find that students learn more, especially in class. Moreover, faculty use CL because they want to build learning communities among their students. They also want to produce well-rounded graduates (i.e., with good interpersonal and team skills in addition to technical skills), who will be better prepared for the real world. Last but not least, faculty who use $\mathrm{CL}$ derive greater satisfaction from their teaching.

\section{EFFECTS ON STUDENT ATTITUDES AND LEARNING; STUDENT PERSPECTIVE}

Student perspective on student attitudes and learning was assessed using: (a) a student survey on the effectiveness of $\mathrm{CL}$, and (b) student comments on how they feel about CL.

\section{A. Student Survey}

Six faculty representing four different programs (Aerospace, Mechanical, Civil, and General Engineering) used the survey in their courses. Data were collected between fall 1996 and spring 1999. The courses, in which the survey was administered, the number of

\begin{tabular}{|l|l|c|c|c|}
\hline \multicolumn{1}{|c|}{ Course No. and Title } & $\begin{array}{c}\text { Course } \\
\text { Level }\end{array}$ & $\begin{array}{c}\text { No. of } \\
\text { Sections }\end{array}$ & $\begin{array}{c}\text { No. of } \\
\text { Responses }\end{array}$ & $\begin{array}{c}\text { Total } \\
\text { En rollment }\end{array}$ \\
\hline E 10: Introduction to Engineering & Freshman & 3 & 107 & 122 \\
\hline CE 96 D: Computer-Aided Design & Freshman & 1 & 26 & 28 \\
\hline ME 111: Fluid Mechanics & Junior & 3 & 116 & 119 \\
\hline ME 113: Thermodynamics & Junior & 1 & 51 & 63 \\
\hline AE 162: Aerodynamics & Junior & 1 & $\mathbf{8}$ & 10 \\
\hline AE 167: Aerospace Propulsion & Junior & 1 & 11 & 12 \\
\hline AE 170B: Spacecraft Design & Senior & 1 & $\mathbf{8}$ & 8 \\
\hline
\end{tabular}

Table 4. Courses used to assess the effects of CL on student attitudes and learning. 
sections and the total number of responses in each course are shown in Table 4.

The survey had forty statements under the following six categories:

(a) Student attitudes related to teamwork.

(b) Course-related gains. (c) Collaboration.

(d) Team/interpersonal skills.

(e) Communication skills.

(f) Problem-solving skills.

Some of the statements in the survey were adapted from reference 10.

\section{Statements}

\begin{tabular}{|c|c|c|c|}
$\begin{array}{c}1^{\text {st }} \text {-year } \\
\text { course } \\
\text { average }\end{array}$ & $\begin{array}{c}3^{\text {rd }} \text {-year } \\
\text { course } \\
\text { average }\end{array}$ & $\begin{array}{c}4^{\text {th }} \text {-year } \\
\text { course } \\
\text { average }\end{array}$ & $\begin{array}{c}\text { All- } \\
\text { Course } \\
\text { Average }\end{array}$ \\
\hline
\end{tabular}

On Attitudes Related to Teamwork

1. I enjoy working $w$, others in and outside the classroom (studying together, solving problems, preparing for tests, or performing experiments in the lab).

2. I prefer to work independently.

3. Working $w$. others feels less stressful than performing similar tasks alone.

4. Knowing that my work affects my partners' grades, makes me try harder.

5 . Knowing that their work affects my grades makes my partners try harder.

6. Shared credit for shared effort is a fair way to grade.

7. My grade should depend only on my own efforts.

8. I am concerned that my teammates cost me points by not doing their share.

On Course-Related Gains

9. Working $w$. others has improved my understanding of the course material.

10. My class scores have been greater as a result of team effort.

11. My teammates were able to help me learn the material in the course.

12. I was able to help my teammates learn the material in the course.

On Collaboration

\begin{tabular}{|l|l|l|l|l|}
\hline 13. My teammates collaborated in doing the assignments. & 3.5 & 3.9 & 3.9 & 3.7 \\
\hline 14. I tried to meet with my teammates but they would not cooperate. & 2.6 & 2.0 & 1.6 & 2.2
\end{tabular}

On Interpersonal / Team Skills

CL has helped me develop my ability to:

15. Reinforce and support ideas.

16. Negotiate agreements and handle conflicts.

17. Encourage open discussion of ideas.

18. Work for and accept compromises.

19. Be aware of other peoples' feelings.

20 . Listen to the ideas of others with an open mind.

21. Ask probing questions that clarify facts, concepts, and relationships.

22. Evaluate arguments and evidence so that strengths and weaknesses of competing alternatives can be judged.

23. Be patient and tolerate ideas/solutions proposed by others.

24. Use discussion strategies to analyze and solve a problem.

On Communication Skills

CL has helped me develop my ability to:

\begin{tabular}{|l|l|l|l|}
\hline 3.7 & 4.1 & 4.3 & \\
\hline 3.2 & 3.1 & 2.9 & 3.1 \\
\hline 3.7 & 4.0 & 3.7 & 3.8 \\
\hline 4.1 & 4.2 & 4.6 & 4.2 \\
\hline 3.5 & 3.8 & 4.0 & 3.7 \\
\hline 3.3 & 3.9 & 4.0 & 3.7 \\
\hline 3.5 & 3.3 & 3.1 & 3.4 \\
\hline 3.4 & 2.5 & 3.6 & 2.9 \\
\hline
\end{tabular}

\begin{tabular}{l|l}
3.7 \\
\hline
\end{tabular}

\begin{tabular}{l|l}
\hline 3.7 & 4.1 \\
\hline 3.4 & 3.9
\end{tabular}

\begin{tabular}{l|l}
3.4 & 3.9
\end{tabular}

3.4

3.6

4.0

3.0

\begin{tabular}{|l|l|}
\hline 4.6 & 4.0 \\
\hline 3.8 & 3.7 \\
\hline 4.0 & 3.7 \\
\hline 3.8 & 3.8 \\
\hline & \\
\hline & \\
\hline
\end{tabular}

4.0

25. Clearly describe problems and ideas orally. 26. Clearly describe problems and ideas in writing.

On Problem-Solving Skills

\begin{tabular}{|l|l|l|l|l|}
\hline 3.5 & 3.9 & 3.9 & 3.7 \\
\hline 3.6 & 3.7 & 3.9 & 3.7 \\
\hline 3.8 & 4.0 & 4.3 & 3.9 \\
\hline 3.8 & 3.9 & 4.1 & 3.9 \\
\hline 3.7 & 3.8 & 4.0 & 3.8 \\
\hline 3.8 & 4.0 & 4.3 & 4.0 \\
\hline 3.8 & 4.1 & 4.3 & 4.0 \\
\hline 3.7 & 3.9 & 4.1 & \\
& & & 3.8 \\
\hline 3.8 & 3.9 & 3.9 & 3.8 \\
\hline 3.8 & 4.0 & 4.1 & 3.9 \\
\hline
\end{tabular}

CL has helped me develop my ability to:

27. Identify what information is needed to solve a problem.

28. Plan my work and set goals.

29. Stay on task while working on a problem.

30. Organize information to make it easier to process.

31. Apply abstract concepts / ideas to real problems / situations.

32. Divide problems into manageable components.

33. Understand that a problem may have multiple solutions.

34. Develop several methods to solve a problem.

35. Define and apply a systematic approach.

36. Recognize contradictions / inconsistencies in ideas, data, etc.

37. Use established criteria to evaluate and prioritize solutions.

38. Recognize flaws in my own thinking.

39. Deal with open-ended problems.

40. Do design.

\begin{tabular}{|l|l|l|l|l|}
\hline & 3.7 & 3.9 & 4.0 & $\mathbf{3 . 8}$ \\
\hline & 3.8 & 3.7 & 3.8 & $\mathbf{3 . 7}$ \\
\hline & 3.7 & 3.5 & 3.8 & 3.6 \\
\hline s. & 3.8 & 3.6 & 3.8 & $\mathbf{3 . 7}$ \\
\hline & 3.7 & 3.7 & 4.1 & $\mathbf{3 . 7}$ \\
\hline & 3.8 & 3.7 & 3.5 & $\mathbf{3 . 7}$ \\
\hline & 4.0 & 3.9 & 3.9 & $\mathbf{3 . 9}$ \\
\hline etc. & 3.9 & 3.7 & 4.1 & $\mathbf{3 . 9}$ \\
\hline & 3.8 & 3.7 & 3.6 & 3.7 \\
\hline & 3.6 & 3.8 & 4.1 & $\mathbf{3 . 7}$ \\
\hline & 3.6 & 3.6 & 4.1 & $\mathbf{3 . 7}$ \\
\hline & 3.7 & 3.9 & 4.4 & 3.9 \\
\hline & 3.8 & 3.9 & 4.1 & 3.9 \\
\hline & 3.9 & 4.0 & 4.4 & $\mathbf{4 . 0}$ \\
\hline
\end{tabular}

Table 5. Summary of student perspective on the effects of CL on student attitudes and learning. Scale: $1=$ strongly disagree, $2=$ disagree, $3=$ do not feel strongly about it, $4=$ agree, $5=$ strongly agree . 
Next to each statement, the students were asked to indicate the extent to which they agreed or disagreed with that statement. The statements of the survey and a summary of the responses are shown in Table 5. The results are discussed in the following subsections:

1. Attitudes Related to Teamwork: Student responses to the first eight questions show that they enjoy teamwork and try harder when they work in a team. Appreciation for teamwork seems to increase from the freshman to the senior year, as students become more mature. Statements 3 and 8 present two exceptions to this increase. The responses to these statements do show a decrease in the level of stress as a result of CL between the freshman and junior years. However, the stress level seems to be going up again as the senior project introduces new demands on student teams and the concerns about non-contributing teammates rise.

2. Course-Related Gains: Here students seem to agree that CL helps them get more out of their classes. Student appreciation for teamwork and team learning increases from the freshman to the junior and senior years. Responses to statement 9 are particularly revealing of this trend.

3. Collaboration: In every class that CL has been used, there are always students who complain that some of their teammates do not collaborate well or that they do not show up for group meetings. This is a serious concern among faculty who use $\mathrm{CL}$, especially because many of the students at SJSU work at least part-time and they do not spend a lot of time on campus. The student responses to statements 13 and 14 are particularly encouraging in this regard, as they clearly show that for most teams this is not a problem and student collaboration improves dramatically by the time they reach the senior year.

4. Interpersonal/Team Skills: Again, students of all levels agree that $\mathrm{CL}$ helps them develop interpersonal and team skills. This result is important because CL may be the only vehicle in the students' education, which provides training in these skills.

5. Communication Skills: Students again indicate that their communication skills improve as a result of $\mathrm{CL}$, especially those in oral communication. This is no surprise, since CL requires student teams to spend a significant amount of time discussing concepts and problems.

6. Problem-Solving Skills: This last category of skills is critical in the assessment of CL. After all, the most important functions engineers perform in the real world are problem solving and design. If CL helped with the development of all the other skills mentioned earlier but did nothing about problem solving, its value in engineering education would be limited. However, as the student responses indicate, CL contributes significantly in the development of problem-solving and design skills. As was mentioned earlier, this result is in agreement with other published research. ${ }^{8}$

In summary, students who have used CL for several years in a variety of courses (seniors) report greater gains from CL than freshmen, who are exposed to CL for the first time.

\section{B. Student Comments on $C L$}

The following student comments are representative excerpts from end-of-semester reflections/evaluations on each course. In some cases (AE 162, ME 111), students are not asked to comment specifically about their experience with CL, however, many feel that their teamwork is one of the highlights of the course. In other cases (MatE 153, MatE 215) students were asked specifically to state their opinion about in-class group assignments.

- I learned the material by first trying to find solutions on my own and then discussing my findings and failures with my teammates. By discussing the solutions in a group I saw the various ways to approach a problem or in some cases the only way, which I may bave overlooked. (Nathan, AE 162: Aerodynamics, Spring 2001)

- I have become a better problem solver because of this class... My ability to communicate and to teach as well as learn from my fellow classmates has been improved and I appreciate the effort the instructor has made to encourage team learning. I have improved my ability to lead a team, as I seem to be drawn to the position of the team leader most often. I have learned how to negotiate and compromise in team decisions and how to better argue my viewpoint and communicate ideas. I have also learned to question almost everything that I hear in an attempt to validate a statement. I strongly feel that the team aspect of this class is one of the best that I have experienced in all my twelve years of college coursework. (Cullen, ME 111: Fluid Mechanics, Spring 2001)

- One of the things that I enjoyed most in this course was the more challenging group problems we did. Working in groups, if done correctly, can cut down on the learning time by a significant amount. This was the case with my group. (Greg, ME 111: Fluid Mechanics, Spring 1999)

- The teams helped a great deal. I studied with my teammates on a regular basis. This helped me understand the material along with getting better grades. The team project of designing and building the bovercraft was one of the highlights of the course. (Ricardo, ME 111: Fluid Mechanics, Fall 1999)

- In-class group assignments are a great approach to foster student interaction. Interactive learning is the best way to accomplish things! I was besitant when you told us we would be doing group work but in the end Ilearned the most from it. (MatE 215: Solid State Materials Engineering student, Fall 1998)

- In-class group assignments are very effective in belping us learn the material. They promote class participation and make time pass quickly. Practice problems really belp with the homework as well as with exam preparation. (The teamwork) helped to get different perspectives on the problems. (Wish) we bad more time for class group assignments. (MatE 153: Properties of Electronic Materials student, Fall 1997)

In summary, students may initially be apprehensive about teamwork due to their lack of experience but they quickly get accustomed to working in groups and acknowledge the benefits of CL. Last but not least, they enjoy their learning experiences, a factor not to be overlooked when we consider student success and retention.

\section{CONCLUSION}

In the COE at SJSU 19 faculty (24\% of the total), representing almost every department, have chosen to adopt $C L$ in their classrooms. The percentage of faculty who use CL is certainly low, considering the evidence in the literature about the benefits of $\mathrm{CL}$ (see for example references 1-5) and the attention the subject has received in engineering education conferences, as well as in the $\mathrm{COE}$ in the last seven years. Nevertheless, the impact on student learning is significant if one considers the following facts:

Each of these 19 professors teaches at least two courses every semester (a conservative estimate considering the teaching load of 12 semester units (four classes) per semester at our institution. Assuming an average enrollment of 30 students in each course (typical 
for engineering courses at SJSU), the result is over 1,000 students (approximately $25 \%$ of the total undergraduate population in the $\mathrm{COE}$ ) who participate in CL every semester. Moreover, every semester, a new group of students benefits from CL, as they take required courses in their disciplines taught by these 19 professors. Thus, the majority of the students in the COE have several opportunities to practice CL before they graduate.

Although showing the effectiveness of CL as a teaching technique was not one of the objectives of this paper-references [2-5] should be consulted for this purpose- both the students and the faculty surveyed reported many benefits as a result of CL, in areas such as improved understanding of engineering concepts, communication, team, problem-solving and design skills. The reported student gains increase from the freshman to the senior years. Assuming repeated opportunities for CL in several classes throughout their stay at SJSU — and that was indeed the case for the students surveyed-this is an indication that students become more skilled in teamwork as they progress through their studies. By the time they reach their senior year they are more mature and more skilled, so they can get much more out of a team project or a team problem-solving session than they could get when they were introduced to CL at their freshman year. Moreover, the preliminary data presented here, although they must be interpreted with caution, show in a more tangible way that $\mathrm{CL}$ may have increased student performance (measured by grades) dramatically in some courses. Thus, CL does indeed contribute to the FIDP goal of "improving instruction to better meet the needs of our students." Last but not least, both faculty and students indicate that they enjoy their classes more when CL is used.

\section{ACKNOWLEDGEMENTS}

This paper was presented as a "lead paper" under the title "Assessing the Effectiveness of a Faculty Instructional Development Program; Part 1: Cooperative Learning," in the $2^{\text {nd }}$ Global Congress on Engineering Education organized by the UNESCO International Centre for Engineering Education in Wismar, Germany, July $2-7,2000$.

\section{REFERENCES}

1. Johnson, D.W., R.T. Johnson, and K.A. Smith, Active Learning: Cooperation in the College Classroom, Interaction Book Co., 1991.

2. Johnson, D.W., R.T. Johnson, and K.A. Smith, Cooperative Learning: Increasing College Faculty Instructional Productivity, ASHE-ERIC Report on Higher Education no. 4, 1991.

3. Johnson, D.W., and R.T. Johnson, Cooperation and Competition: Theory and Research. Interaction Book Co., 1989.

4. Tinto, V., Leaving College: Retbinking the Causes and Cures of Student Attrition, University of Chicago Press, $2^{\text {nd }}$ ed., 1994.

5. Astin, A., What Matters in College: Four Critical Years Revisited, Jossey-Bass, 1993.

6. http://umn.edu/ smith/

7. Felder, R.M., R. Brent, T.K. Miller, C.E. Brawner, and R.H. Allen, Faculty Teaching Practices and Perceptions of Institutional Attitudes Toward Teaching at Eight Engineering Schools, Proceedings, Frontiers in Education Conference, (CD), ASEE/IEEE, 1998.

8. McKeachie, W., Teaching Thinking, National Center for Research for the Improvement of Postsecondary Teaching and Learning Update, vol. 1, no. 2, 1988 .

9. Mourtos, N.J., Portfolio Assessment in Aerodynamics, Journal of Engineering Education, vol. 88, no. 2, 1999, pp. 223-229.

10.Terenzini, P.T., A.F. Cabrera, C.L. Colbeck, J.M. Parente, and S.A. Bjorklund, "Collaborative Learning vs. Lecture/Discussion: Students' Reported Learning Gains," Journal of Engineering Education, vol. 90, no. 1, 2001, pp. 123-130. 